\title{
Jan Chryzostom Pasek i jego badacze - dwie sztuki postaciowania
}

Patrycja Potoniec 
nAPNS Seria IX 2003

\section{Patrycja Potoniec}

\section{Jan Chryzostom Pasek i jego badacze - dwie sztuki postaciowania}

$\mathrm{U}$ czeń szkoly średniej spotyka nazwisko Jana Chryzostoma Paska co najmniej dwukrotnie: gdy zapoznaje się z fragmentani Pamiçmikón' podczas omawiania literatury epoki baroku oraz gdy poznaje sylwetkę I Ienryka Sienkiewicza, dla którego lanmiętniki były inspiracją. Praktyka szkolna dorobila jednak Paskowi Gombrowiczowską gębę, czyniąc z niego

...typowego przedstawicicla polskiej szlachty: warchola i pieniacza ze sktonnością do burd i pijaństwa'.

W świetle badaí archiwalnych, przeprowadzonych przez Jana Czubka, temu schematowi trudno odmówić pewnej dozy prawdziwości. Jednak w cieniu tego wizerunku niesłusznie ginie taka postać Jana Chryzostoma Paska, jaka wyłania się z tekstu Pamiętnikón. Oczywisty wydaje się fakt, iż pisząc lanniętniki zadbat on o swój korzystny wizerunck. Wynikało to nie tylko z naturalnej niechęci do oczerniania siebie, wiązało się także z celem praktycznym szlacheckiego pamiętnika. Miał on być świadectwem istnienia, ale zarazem powinien dawać potomkom powód do dımy, dostarczając im zarazem przykładı do naśladowania. Łączył więc funkcję informacyjną z parenetyczną. Dodając do wrodzonego talentu gawędziarskiego i wykształcenia oratorskiego, wyniesionego z rawskiego kolegium, miłość własną i szacunek do tradycji, Pasek przedstawił siebie jako zacnego reprezentanta stanu szlacheckiego.

Przyjąwszy Cyceroński porządek atrybutów postaci², należy stwierdzić, że te spośród nich, które posiadał Pasek, występują w pozytywnym aspekcie. Już zaczynając od nazwiska, które stanowiło powód do dumy. Określało ono przynależność do stanu, wiązało się z chwałą

Cytat zaczerpuiçty z zeszytu liccalisty.

2Należą do niego: 1. imiç; 2. natura (wrodzone waściwości): 3. stanowisko i majątek; 4. tryb życia; 5 . nabyte uniejętności; 6. usposobienie; 7. zannitowania intelektualnc: 8. zaniary (cele i plany): 9. czyny: 10. uydarzenia 
przodków, wskazywało pochodzenie regionalne i bylo świadectwem rozmaitych więzów pokrewieństwa. Autor Pamiętrnikóu' przejawial widoczną dumę ze swego pochodzenia, podkreślał przynależność do stanu: „nie bądźmy hierozolimskąa , ale polską szlachtą, pamiętajmy na Boga i ojczyznę"† — zwracal się do uczestników pospolitego ruszenia, chcąc pobudzić ich odwage. Jako szlachicic miał poczucie wplywu na losy państwa - w relacji z elekcji Michała Wiśniowieckiego prezentował siebie jako jednego z animatorów wyboru „króla Piasta”. Przejawial również dumę z osiągnięć swoich krewnych, wszak były także świadectwem godności rodu: przy toczył pochlebną opinię posłów rosyjskich na temat swego stryja i podkreślał udział bratanka w odsieczy wiedeńskiej.

Inny Cyceroński atrybut postaci — stanowisko i majątek — również stanowi istotne zagadnienie postaci Paska. Przyznawal, że pochodzi z rodziny niezbyt zamożnej, ale podkreślal swoją zdolność do „urobienia substancyi” i zamiłowanie „ad pinguam glacbam”, które pozwoli mu po zawarciu małżeństwa na zdobycie majątku. Przedstawiał siebie jako dobrego gospodarza, który doskonale wie, że „pańskie oko konia tuczy”, więc stara się dopilnować swoich interesów, czasem nie bacząc na przeszkody (na przykład natychmiast po podniesieniu się z ciężkiej choroby ruszył ze spławem zboża). Zadowalalo go niezbyt wiele, przynajmniej w sferze deklaracji, reprezentowal więc taką postawę wobec dóbr materialnych, jaka wynikała z ideału „zlotej mierności”. Pasek nie piastował zbyt wysokich stanowisk, posiadał niewiele znaczący tytul komornika rawskiego (potem krakowskiego), ze szczególami opisał więc pełnienie funkcji przystawa przy poselstwie rosyjskim. Brak wyżzego stanowiska zrekompensowat, przedstawiając swoje stosunki z możnymi tego świata, mial osobiste kontakty z królami: Jan Kazimierz chwalił go za postawę wobec magnackich oskarżeń, Jan III Sobieski podziwiał jego dowcip i talent do oswajania zwierząt. Również Stefan Czarniecki, którego Pasek bardzo cenil, odwzajemnial jego poważanie.

Tryb życia, kolejny z Cycerońskich atrybutów postaci, również został przedstawiony w Pamiętnikach jako godny pochwały. W młodości Jan Chryzostom podjął służbę wojskową dla ojczyzny, mimo obaw rodziców uczestniczyl nawet w dalekiej wyprawie duńskiej. Jako żołnierz korzystal z uroków życia, ale umial też poradzić sobie w surowych warunkach polowych (przykładem nocleg na polu bitwy z glową na brzuchu zabitego Moskala). Po zakończeniu kariery wojskowej rozpoczął Pasek, stosowny dla szlachcica, żywot ziemiański. Zawarl małzeństwo z równą 11 u stanem kobietą i gospodarzył w folwarkach, czasem tylko urządzając polowanie, jeżdżąc na rozprawy sądowe lub sejmiki wojewódzkie. Cały bieg własnego żywota opisal jako spełniający kryterium stosowności dla człowieka jego stanu i kondycji finansowej.

losowe; 11. sposób wypowiadania siç (Cyceron, De innentionn' 24, 34, za: T. Michałowska, Bohater literacki |hasho w: Shomik litcritury staropolskicj. red. T. Michahowska. Wrochaw 1998).

"Czyli zydowską. tchórzliwą.

+ J. Pasek, Pamiq̨imiki, opr. W. Czapliński. Wroclaw 1968 (BN I 62), s. 205.

${ }^{5}$ Ibidem, s. 430. 
Dumę przejawiał też Pasek, opisując nabyte przez siebie umiejętności: na przykład właśnie jego wyshano do Ebeltoft „na deputacyją, najbardziej respektem języka łacińskiego”, któryın władał lepiej niż towarzysze. Równie chętnie popisywal się enudycją w przytaczanych mowach, gęsto przetykanych lacińskimi zwrotanı i przykladami z historii starożytnej. Bezwzględnie podkreślał swą przewagę w tej materii nad innymi mówcami:

Jakem ja skoníczyl, mówil pan podczaszy Gumowski bardzo facunde, crndite, ale że sobie pomięszal sens et connexiones, i zaraz to było znać, kto się znał na rzeczy'.

Oczywiście sam Pasek, jak latwo się domyślić. Zresztą swój sıkces krasomówczy uważał nie tylko za wynik edukacji, lecz także wrodzonych umiejętności, co w jego relacji potwierdzać mają także inni szlachcice, na przykład pan Tyszkiewicz. Dowcip i wymowność naszego bohatera podziwiali nawet królowie. I)bał zresztą Pasek o swoją edukację — jako szkołę dla szlachcica najwłaściwszą wskazywał przysłuchiwanie się obradom sejmu:

...wszystkie na świecie publiki cień to jest przeciwko sejmom. Nauczysz się polityki, nauczysz się prawa, nauczysz się tego, o czym w szkolach jako żyw nie slyszaleś ${ }^{7}$

— pisal. Szczycil się także posiadaniem umiejętności żohnicrskich, z lubością opisywal zadawane przez siebie ciosy, a także manewry, jakie przeprowadzał jego oddział. Również jako osiadly ziemianin opisywał chętnie swoje osiągnięcia zarówno w dziedzinie uprawy i sprzedaży produktów rolnych, jak i w szlacheckiej rozrywce, jaką bylo polowanie i układanie zwierząt (tutaj doskonałym przykladem jest popularna historia o arcymądrej wydrze). Potrafil takze poradzić sobie w sądzie i na sejniku. Dysponowal więc wachlarzem umiejętności potrzebnych osobie jego stanu, rozwijal te wrodzone i chętnie uczyl się nowych. Trudno powiedzieć, by żywil jakieś glębsze zamiłowania intelektualne, naturalnie poza oratorstwem, w którym chętnie się ćwiczyl i które podziwiał na sejmach. Można też uznać, że pociągaly go rzeczy nowe: wybrat się do Danii, wiedziony nie tylko poczuciem obowiązku, lecz także ciekawością. Z lubością opisywal niezwykle cudzoziemskie zwyczaje i niejednokrotnie narażal się na niebezpieczeństwa, by zdobyć nowe doświadczenia. Na przykład podezas wizyty na statku pozostał na pokładzie i tym samym wziąl udzial w bitwie morskiej, choć towarzyszący mu szlachcic pośpiesznie wrócil na ląd w obliczu nadpływających wrogich okrętów.

O usposobieniu Paska można wnioskować jedynie na podstawie stosunków z innymi ludźmi. Na wojnie prezentowal siebie jako krewkiego i petnego odwagi, nie pozwalał na najmniejszą ujmę na swoim honorze. Impulsywność przejawiał też w czasie pokoju, gwaltownie zareagował na podejrzenia, jakoby był zdrajcą, bardzo szybko zdecydowal się na zawarcie małżeństwa, bez namysłu ukaral shugę podejrzanego o kradzież, choć jego wina nie została udowodniona. Przedstawione przez niego stosunki z dziećmi żony pokazują go jako czlowie-

\footnotetext{
Ibidem, s. 369 .

Ibidem, s. 358 .
} 
ka dobrotliwego i sprawiedliwego, choć spotykały go z powodu „dziecinnych interesów” rozmaite klopoty:

To tak pojąć wdowę z dziećni i z klopotami; pierwszy mąż zaciągnie długi, zostawi klopoty, dzieci, litigia, a ty dla cudzych interessów uschniesz, zdrowie stracisz $z^{\circ}$

— pisał z goryczą, podkreślając później, że wyprocesowaną wieś

...na jedno pasierba uniżenie a przyjaciól instancyją darowałem, nawet i dożywocia [które należało się żonic - P. 1.] ustąpilem, nic za nie nie wziąwszy; nawet pierzcień, który mi byla dała żona na zmowę, oddałem, żeby przy mnie nic nie przysychalo cudzego".

Jego cele i plany - kolejny z Cycerońskich atrybutów postaci - nie były zbyt wygórowane. Holdowal zasadzie umiaru, obral zwykłą karierę niezbyt zamożnego szlachcica: wstąpil do Czarniecczyków nie tylko z patriotycznego obowiązku, lecz także w nadziei wzbogacenia się, co pozwoliłoby mu osiąść na swoim folwarku i czekać na „synków”. Jego praktyczny umysł nie pozwalal mu snuć zbyt dalekosiężnych planów, wolał poprzestawać na małym. Powzięte zamiary realizował z dużą konsekwencją, lecz godzil się z tym, że nie wszystko może osiągnąć - nie doczekal się na przykład potomka. Podkreślał swą zgodę na to, że wola Boża jest ponad ludzkimi zamiarami.

Bohater Pamiçtnikón' zostal scharakteryzowany glównie poprzez swoje czyny, Pasek nie był skłonny do autorefleksji; tak siebie, jak innych postrzegał przez pryzmat dzialań. Dlatego najszczegółowiej opisywał te zdarzenia, w których miał okazję odznaczyć się jakimś chwalebnym czynem. Stąd najdluższa część Pamiętnikóu' poświęcona zostala okresowi jego kariery wojskowej, późniejszy żywot ziemiański nie dostarczał już tak obfitego materiału, choć wspominał Pasek równiez o swej rzetelności jako gospodarza i umiejętności dbania o swój majątek. Wojenne zasługi uznawano jednak za przynoszące większą chwałę. Byly także najbardziej interesującą materią gawędy. Dzialanie było tym, co dawało najlepsze świadectwo wszelkich cnót, więc Pasek z lubością opisywał swoje przewagi wojenne, choćby tylko nad bogatym mlodzieniaszkiem.

Jednak nawet największy bohater może stać się igraszką losu - spotykające go wydarzenia losowe też stanowią atrybut postaci. Dla Paska najgorszym była bezdzietność. Niemało miejsca poświęcil też pechowi prześladującemu jego rumaki, podał go nawet za przyczynę wystąpienia z wojska. Rozważanie zrządzeń losu nie należało jednak do zwyczajów pamiętnikarza, uznawal Boskie wyroki za słuszne inie próbowal z nimi dyskutować. Dlatego wydarzenia losowe w jego relacji są na ogól pozbawione komentarza.

\footnotetext{
${ }^{8}$ Ibidem, s. 559
}

"Ibidem. s. 560 ). 
Ostatnim z wyróżnionych przez Cycerona atrybutów postaci jest sposób wypowiadania się"'. W Pamiętrikach znajdıjemy co najmniej dwa odmiemme od siebie typy wypowiedzi: narrację pamiętnikarską oraz mowy". Tok narracji rozwijany jest z gawędziarskį swadą i dużą dbałością o szczególy. Wyeksponowanym jedıak przez Paska sposobem wypowiadania się są zapisane przez niego mowy, jakie ponoć mial wygłaszać w różnych momentach swego życia. Oratorskie zdolności i umiejętności napełniały go szczególną dumą. Chciał nimi zaprezentować się jako jednostka wybitna i uczona, której wymowność jest w stanie sprostać senatorskiej. Nie stronił od karkołommych wręcz konstrukcji retorycznych, by tym lepiej dowieść swojej swady.

Przyjąwszy Cycerońskie atrybuty postaci jako porządek oceny etycznej postaci Paska, 11ależy zauważyć, że posiadat on liczne cnoty przy niewielı wadach. Mógł być dumny ze swego pochodzenia, rozwijał wrodzone umiejętności, chętnie i latwo nabywał nowe. Realizował ideał złotej mierności, wywiązywał się wzorowo z obowiązków obrońcy ojczyzny, gospodarza i głowy rodziny. Dla udowodnienia swoich cnót przytaczał wiele chwalebnych uczynków. Prowadził tryb życia wlaściwy dla swojej kondycji spolecznej i finansowej. Był moze zbyt krewki, ale rekompensowal to poczuciem sprawiedliwości i dobrocią. Mówiąc wprost: bohater bliski ideatu.

Jednak nie jest to jedyny wizerunek Jana Chryzostoma Paska, jaki możemy odnaleźć w naszej literaturze. Pamiętniki od chwili pierwszego wydania w 1836 roku wzbudzają wciąż duże zainteresowanie badaczy. W ich oczach postać Paska prezentuje się zgoła inaczej. Szczególnie wyraziście jest to widoczne w wypowiedziach zwolenników tezy, że dzieło Paska nie ma charakterı dokumentalnego, lecz jest romansem historycznym. Taką tezę wysumąh juz Joachim Lelewel, a powtórzył za nim Adam Mickiewicz, w W'kładach par’skich mówiąc o Pasku:

Odgadnął on, że tak powiem, rodzaj literacki romansu historycznego ${ }^{12}$.

Podzieliwszy zachwyt Paska dla samego siebie, docenial jego cnoty i przedstawiał go jako szlachcica pozytywnie odbiegającego od ogółı. 1)o twierdzenia o romansowym charakterze Pamiętnikóu powrócił Ignacy Chrzanowski w 1906 roku w Historii literatury niepodległej Polski, a rozwinąl tę koncepcję Aleksander Brückner we wstępie do krytycznego wydania w edycji Biblioteki Narodowej w 1924 roku. Prace obu tych znakomitych historyków literatury pojawily się jednak już po przeprowadzeniu przez Jana Czubka badań archiwalnych — dowiodły one bezsprzecznie, że dzieło Paska jest autentyczne, choć początkowo wzbudzało pewne podejrzenia. Korzystając z krakowskich archiwów sądowych, Jan Czubek zapoczątkowal kształtowanie nowego wizerunku Paska. Kiedy okazało się, ze Pamį̨tmiki przedstawiały wydarzenia w odmiennym oświetleniu niz akta procesowe, została otwarta istna puszka Pandory,

\footnotetext{
1" Szerzcj o sposobach wypowiadania się Paska w: O jezłkn isty'm Jama Chyzostoma Paska. red. H. Rybicka-Nowacka, Warszawa 1989

"Inne wypowicdzi - jak cytowane listy i publicystyka (paszkwil na Prażmowskiego) - posiadająodmienny status.

12 A. Mickicwicz, Dzicta, Warszawa 1952, t. 10, s. 30 .
} 
co przyniosto zdeprecjonowanie postaci Paska. Sam Czubek, mimo dowiedzionych przez siebie nieścisłości popełnionych w Pamiętnikach przez ich autora, przedstawil pozytywną ocenę Paska:

...energia, rzutkość, ruchliwość, waleczność i odwaga osobista, pewien rodzaj patriotyzmu, gotowość do usług i latwość w pożyciu z ludźmi, rubaszny humor połączony z niby uczoną swadą XVII wieku, te i inne zalety charakteru Paska, jak nas dotąd zachwycały, tak i naszych potomków, rzec można, nawet najpóźniejszych zachwycać będą̧ ${ }^{13}$.

Zaraz jednak dodat:

Dokumenta więc nasze nie wywracają dotychczasowego sądu o Pasku na nice, lecz podkreślając jedynie grubicj wady i cienie, przesurwają go ku stronie lewej, ujemnej; traci na tym nieco wytworna strojnisia poezja, ale zyskuje naga prostaczka prawdat.

To ,przesunięcie ku stronie lewej” powięksszało się coraz bardziej w toku dalszych badań. W Historii literatury niepodleggtej Polski opublikowanej w 1906 roku znajdujemy juz taką ocenę Paska:

Był to człowiek żywy i ruchliwy, porywczy i gwaltowny, w gorącej wodzie kąpany; wesoły, jowialny, gadatliwy, pełny animuszu rycerskiego i fantazji, ale o głowie ciasnej i sercu małym; pieniacz, chciwy grosza i procesıjący się o byle co po calych latach, choćby o jedną głupią krowę; do tego pijak, awanturnik, zawadiaka, kłótnik ${ }^{15}$.

Fragment ten został umieszczony prawie na samym początku hasła poświęconego Pamiętnikom. Następne dwie i pół strony zajmuje pogłębiona charakterystyka Paska: „miłością bliźniego ani drażliwością sumienia nie odznaczał się"; , był nieludzki i okrutny”; „modlił się pod figurą, a diabła mial za skórą”. Tryb życia prowadził hulaszczy: „często się upijał, pojedynkował się przy każdej sposobności i urządzał zajazdy na cudze domy”. Paskowy patriotyzm opisal Chrzanowski jako zaściankowy. Nie zakwestionowal dzielności w boju, pozytywne uwagi opatrzył jednak komentarzem na temat szlacheckiej interesowności. Najmocniejsze argımenty zawarł w opisic działań Paska, zastosowal więc tę samą co autor Pamiętnikóu' zasadę: najsilniej przemawiają czyny. Dlatego właśnie na kartach Historii literatury niepodległej Polski zostały wspomniane zaczerpnięte z akt sądowych opowieści o tym, jak Pasek zmusil wchodzącego mu w szkodę pachołka do zjedzenia surowego zająca albo jak morzyl głodem uwięzionego kowala. Długie omówienie osobowości autora Pamiętnikóu zakończyl Chrzanowski zdaniem pełnym goryczy:

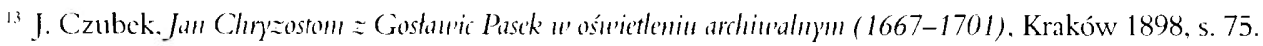

"H Ibidem.

15. Chrzanowski. Historia literatury' niepodlegtej Polski, Warszawa 1971, s. +39 
Otóż ten lichy czlowiek jest autorem najlepszych w catej literaturze staropolskiej pamiętników.

Negatywny obraz Paska uzupełnił Aleksander Brïckner w 1924 roku, oskarzając go przy okazji o zakłamanie. Oskarzenic to straciło, co prawda, nieco sens w kontekście opinii, że dzieło Paskowe w ogóle nie jest pamiętnikiem, a jedynie romansem historycznym. Jednak istotnymi cechami ich bohatera okazało się to, że „Pasek o niczym nie wiedziat i w żadną sprawę nie byl wtajemniczony”; ., nie imponuje nam myślą czy wiedzą”, a „pogląd na świat ma arcynaiwny”. .O wiedzy jego również niewicle chlubnego powiemy (...) i polityk z niego nietęgi” - „szlachcic przeciętny, od pesymizmu i bólı patriotycznego Kochowskiego i Potockiego jak najdalej stroniący, nie zdaje sobie sprawy o stanie kraju”. Najpehniej jednak opinię Brücknera o Pasku oddaje jego ocena motywów powstania Pamiętnikóu":

Bezpotomny starzec chcial przynajmniej na piśmie zostawić po sobie pamiątkę i opisal bieg życia (...). Fantazja starcza wrócila do lat młodzieńczych, zapowiadających loty górniejsze, opadających w końcu na poziom nizszy od przeciętności, chyba nie bez winy człowieka, co wyższe ambicje pogrzebał. Ta fantazja ukraszała, uróżowała owe początki $(\ldots)^{16}$.

Powojennym spadkobierca Brücknerowskich teorii był Roman Pollak. Przygotowal on nową edycję Pannį̧tnikón', a w poprzedzającym je Wstępie uzupehnił charakterystykę Paska o nowe niepochlebne szczególy, poświęcił między innymi obszenny fragment jegro mazowieckiemu pochodzeniu. Na Mazowsze wedhug niego

...nie dochodzity prądy reformacyjne, nie dotarły echa Renesansu, natomiast kontrreformacja zapanowała od razu niepodzielnic, a z nią fanatyzm wyznaniowy i dewocja (...). Przesądy i zabobony trzymały się w tym środowisku uporczywie, obok nich zaś w obyczaj weszło pijaństwo i pieniactwo, skłonność do pojedynków i zwad ${ }^{17}$.

Możemy się też dowiedzié, że jezuickie kolegium w Rawie „wciąż zostawało w tyle za innymi tego rodzaju uczelniami”, a szkolną edukację Paska należy ocenić jak najgorzej, lącznie z wysłaniem do piekła „rawskiego ojczaszka”, który ,zaprawial naszego bohatera do rymotwórstwa". Równie surowo ocenione zostały laskowe przewagi wojenne:

W pogoni za nieprzyjacielem chudopacholska chciwość na łup, na zdobyczne konie wprost z orbit mu wysadzala drapieżne oczy ${ }^{\text {Is }}$.

Za Paskowe przywary winnym téz czyni Pollak ideologię sarmatyzmu: zwyrodniałą, pethą

th A. Brückner. Il'stęp do: J. Cl. Pasck. Pamiętriki, Kraków 1924, s. 8 i nast.

17 R. Pollak, U'step do: J. Ch. Pasck. Pamiçniki, Warszawa 1955, s. 12.

ix Ibidem. s. 22. 
...gadulstwa, pustej ceremonialności, zamiłowania do wszelkiej pompy, uroczystych procesji, pogrzebów, hucznych biesiad, pustego sejmikowania, pieniactwa i pijaństwa".

Podobnie jak jego poprzednicy (Chrzanowski i Brückner), Roman Pollak doceniał wartość Pamiętnikón' jako dzieła literackiego, ale nie mógł dokonać pozytywnej oceny etycznej ich autora.

Trójgłos badaczy składa się na portret Paska skrajnic odmienny od tego, jaki on sam Pamiętnikami przedstawił. Podsumowując opinię tych historyków literatury, można sformułować taką charakterystykę naszego bohatera: pochodził ze szlachty mazowieckiej, ubogiej, zaściankowej i źle wykształconej. Takie pochodzenie sprawiło, że jego wrodzonymi cechami stały się chciwość i pieniactwo (R. Pollak). Pozycja, jaką udało mu się osiągnąć, to urząd niskiego szczebla, a poufalość z wyżej postawionymi to tylko „starcze fantazje”. Tryb życia, jaki prowadzil, był typowy dla uboższej szlachty i sprowadzał się do pijaństwa i dewocji. Nie potrafil nawet zająć się swoim folwarkiem, musiał do pomocy sprowadzić rodziców i korzystać z doświadczenia żony (R. Pollak). W stosunkach z innymi był okrutny, nieczuly i krwiożerczy. Nie miał pojęcia o otaczającym go świecie i gustował w niewybrednych rozrywkach, jego horyzonty myślowe okazywały się wąskie, a patriotyzm prymitywny. Aspiracje posiadał zbyt niskie, a z biegiem lat zeszly one „poniżej poziomu przeciętności”. Nie sposób zaprzeczyć jego dzielności w boju, ale wynikała ona jedynie z "chudopacholskiej chciwości”, czynów godnych pochwaly dokonywal tylko dlatego, ze spodziewał się nagrody. Miał na sumieniu wiele haniebnych uczynków, ale przedstawiał je klamliwie lub przemilczał. Wobec wyroków losu zachowywal się zbyt biemie, zanadto ufał w opiekę Boską nad sobą, a zarazem jego religijność pozostawala powierzchowna. Pamiętnikom nie sposób odmówić wartości literackiej, ale „czad szkolnej retoryki zagnieździł się w nich na zawsze"-2". Nie tylko są one klamliwe, ale na domiar złego w ogóle nie można ich uznać za pamiętnik, tylko za romans historyczny. Tu katalog Paskowych grzechów się kończy, lecz zgromadzono ich już wystarczającą liczbę, by można było stwierdzić, że prawie wszystkie z jasnych stron Paska przedstawionych przez niego samego mają swój mrocznią przeciwwagę w opinii badaczy historii literatury. Każdy z Cycerońskich atrybutów postaci, które zostały mu przypisane w pierwszej części niniejszego artykułu (atrybutów nacechowanych dodatnio!) otrzymal teraz znak ujemny.

${ }^{14}$ Ibidem. S. 34.

2) R. Pollak, It stęp.... s. 40. 
Atrybut

Imiç

Natura

Stanowisko i majątck

Tryb życia

Nabyte umicjętności

Usposobicnic

Zamiłowania intelektualne
Pasck w Pumiętrikikach

Dumny z nazwiska, rodu i krewnych

Ma osobiste kontakty z królalmi. Realizuje ideal ,zlotej mierności", jest dobrym gospodarzem

Szlachecki ideal - w modości rycerz, w wicku dojrzałym zicmianin

Wykszatalcony, whada taciną, doskonaty orator

Na wojnic: odwaziny, porywczy, honorowy; w domu: dobrotliwy, życzliwy, lojalny, sprawiedliwy, oddany ojczyźnic w czasic wojny i pokoju

Cickiwość świata, doskonalenic umicjętności oratorskich
Pasck wedlug jego badaczy

(I. Chrzanowskicgo,

A. Brïcknera, R. Pollaka)

Pochodzil z Mazowsza, gdzie ,nic dochodzily prądy reformacyjne, nic dotarly echa rencsansu, natomiast kontrreformacja zapanowala od razu nicpodzichnic, a z nią fanatyzm wyznaniowy i dewocja"

..Szlachcic przeciçtny, od pesymizmu i bólı patriotycznego Kochowskiego i Potockicgo jak najdalcj stroniący"

Sprawowal urziad niskicgo szczcbla

.Czçsto siç upijal. pojedynkowal siç przy każdcj sposobności i urządzał zajazdy na cudze domy"

..Pasck o niczym nic wicdzial i w żadna sprawe nic byl wtajemniczony", "nic imponuje nlam myślą czy wiedzą"

"Byl nicludzki i okrutny". Zmusil pacholka do zjodzcnia surowego zająa i morzył glodem uwiçzionego kowala

Pochodzi ze środowiska, gdzic „przesądy i zabobony trzymaly siç uporczywic". A nauczycicla, który ,zaprawial naszego bohatera do rynotwórstwa", należatoby wystać do pickla 
Zamiary (cele i plany)

Czyny

Wydarzenia losowe

Sposób wypowiadania siç
Wedle zasady mierności poprzestawanic na malym, życic zgodne ze statusem spotecznym i majątkowym, kontynuacja rodu

Wojenne zasługi, dbanie o swój majątek z należytą rzetelnością, zdolność do „urobienia substancyi", umicjętne dochodzenic swych praw w sądzic

$\mathrm{Na}$ wojnic: utrata rumaków, w późnicjszym życiu bezdzictność

barwna gawęda, facecja, nowy
„Czlowick, co wyższe ambicje pogrzcbal"

„W pogoni za nieprzyjaciclem chudopacholska chciwość na lup, na zdobyczne konie, wprost $z$ orbit mu wysadzala drapicżne oczy"

Bezdzictność

nieszczerość, koloryzowanie

Wlaściwie tylko wydarzenia losowe, które spotkały Paska, nie zostały ocenione przez historyków literatury negatywnie. Wszelkie pozostałe atrybuty tej postaci, widziane oczani cytowanych już wyżej badaczy, ukazują liczne wady pamiętnikarza.

Skąd ta rozbieżność? Zanim podejmiemy próbę odpowiedzi na to pytanic, trzeba podkreślić, że opinie Chrzanowskiego, Brücknera i Pollaka nie sajedynymi. Tylko po II wojnie światowej Pamiçtnikami zajmowali się: Władysław Czapliński, Alojzy Sajkowski, Jadwiga Rytel i imni, nie mniej cenieni badacze. Jednak to nurt reprezentowany przez Chrzanowskiego, Brücknera i Pollaka zaważył najsilniej na powszechnej opinii o Janie Chryzostomie Pasku. Dlaczego? Powodów jest kilka i trudno stwierdzić, który z nich okazal się przeważający. Po pierwsze: Ignacy Chrzanowski i Aleksander Brückner to naukowcy o wielkim autorytecie i ogromnej sile oraz zasięgu oddziaływania. Historia literatur' n' niepodlegtej Polski przez lata stanowiła podstawę kształcenia historycznoliterackiego, a zaslugi Aleksandra Brücknera dla badań nad historią naszej kultury trudno wprost przecenić. Po drugie: wszyscy ci trzej historycy literatury posługiwali się stylem nadzwyczaj przystępnym i barwnym, czytelnik łatwo ulega jego urokom, a co z tego wynika, takze przedstawianym argumentom. Po trzecie: ich opracowania (kompendium wiedzy o historii literatury Chrzanowskiego oraz wstępy do Pamiętnikóu, Brücknera i Pollaka) mają charakter popularnonaukowy, mogą być zrozumiane przez niespecjalistę. Tymczasem prace pozostałych badaczy wymagają bardziej specjalistycznego przygotowania lub przynajmmiej dużego zainteresowania tematem, z wyjątkiem może również popularnonaukowego wstępu Wladysława Czaplińskiego, jednak jego styl nie jest tak sugestywny jak poprzedników. Po czwarte: niechętny stosunck tych badaczy do Paska pasował do obowiązıjącej po II wojnie światowej negatywnej oceny okresu Rzeczypospolitej szlacheckiej. Z tych czterech powodów wynika zapewne popularność niekorzystnego wizerunku postaci Paska. 
Powróćmy jednak do pytania, dlaczego wizerunek w oczach badaczy jest tak odmienny od tego przedstawionego w Pamiętnikadh. Różnica wydaje się na tyle glęboka, że wywołuje wrażenie, jakby istniało dwóch Janów Chryzostomów Pasków. Przyczyn takiego stanu rzeczy w badaniach nad Pamięmikami i życiem ich autora można wskazać kilka.

Po pierwsze: uchybienie wobec metodologii badań literackich, jakiego dopuścili się badacze. W ich interpretacji autor, narrator i bolater Pamiçtnikóu' to jedna i ta sama postać. Przyjmując jednak poczynione przez nich (zwlaszcza przez Brïicknera i Pollaka) założenie, że dzieło Paska to nie pamiętnik, tylko romans historyczny, nie można pozwolić sobie na powyższe utożsamienie. Zwlaszcza autor i bohater muszą zostać rozróżnieni, tak jak zostalo to zrobione w badaniach nad innymi utworani literatury. Tożsamość imienia i nazwiska, a nawet podobieństwo kolei życiowych nie może stać się podstawą upraszczającego utożsamienia. Użycie pierwszej osoby liczby pojedynczej w narracji usprawiedliwia jedynie uznanie identyczności narratora z bohaterem (tym bardziej, że świadomość istnienia narracji u literatów staropolskich była mało wyraźna) ${ }^{21}$. Natomiast bohater i autor powinni zostać wyraźnie rozróżnieni ${ }^{22}$.

Drugim powodem rozbieżności w wizerunku postaci Paska w Pamiçtnikach i w pracach historyków literatury staly się badania archiwahne, które dowiodly, że niektóre wydarzenia miaty inny przebieg, niz zostako to opisane w Pamiętnikach. Niewątpliwie akta sądowe stanowią bardziej wiarygodne źródło dokumentacji faktograficznej niż dzicło Paska. Z dwoma jednak zastrzeżeniami: często zawierają informacje podane przez Paskowych oponentów i inny jest cel ich sporządzania. Bowiem, analizując szlachecki pamiętnik, nie możeny tracić z oczu (wskazanego juz na wstępie niniejszego wystapienia) celı praktycznego, dla którego tekst ów powstawał. Celem tym nie było bynajmniej dokumentalne przedstawienie wydarzeń (choć i takie pamiętniki się zdarzały), lecz zaznaczenie swojego istnienia jako „ogniwa” w „łańcuchu” genealogicznym. Należało znaleźć w nim godne miejsce: dorównać slawie przodków i dać powód do dumy potomkom. Taki cel dla swojego dzieła wskazywał zresztą sam Pasek. pisal przecież, że ma ono być „opisaniem życia”,

...dla synków dowodem, żem florem aetatis nie na próżnowaniu stracil i w tych bywatem, jako szlachcicowi należy, okazyjach ${ }^{23}$.

Pewna niezgodıość z prawdą może więc zostać usprawiedliwiona wlaściwościami gatunku piśmienniczego obranego przez Paska.

Pojawiające się u niego przeklamania stanowią trzeci powód niekorzystnego wizerunku pamiętnikarza w oczach badaczy. Raz podważone zaufanie do jego informacji nie mogło już zostać przywrócone. Podejrzliwie odnoszono się więc do wszystkich opisywanych przez niego faktów, często popadając w przesadę. Doprowadziło to do zanegowania wartości Pamiçtmi-

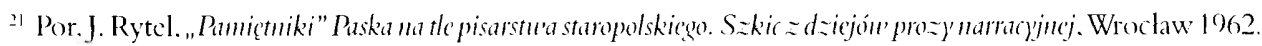

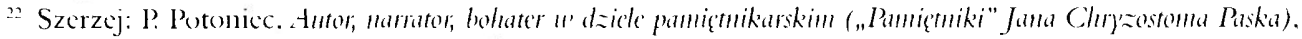
..Acta Universitatis Nicolai Copernici. Filologia polska LVII" 20)2 2. z. 354, s. 3.

${ }^{23}$ J. Pasck, Pamiçtmiki. cd. cit., s. 272. 
kóu jako źródła historycznego, co zweryfikował dopiero Wladyslaw Czapliński, dowodząc ich przydatności dla badań historycznych ${ }^{2+}$.

W związku z powyższyın powstaje kolejne pytanie: dlaczego sila perswazji badaczy Paskowego dzieła przeważyla nad jego własną? Oczywiście zaważyły na tym uwarunkowania historyczne, ale należy uwzględnić również kilka innych powodów. Pierwszym wydaje się wspomniany już wyżej autorytet Ignacego Chrzanowskicgo i Aleksandra Brïcknera. Drugim: dystans czasowy - mentalność siedemnastowiecznego szlachcica może być zbyt obca dla współczesnego czytelnika. Trzecim: zanniłowanie odbiorców do prawdy, w jej najprostszej, to jest upraszczającej postaci, połączone z niewiedzą na temat staropolskich konwencji gatunkowych. Czwartym: zadowolenie, jakie odczuwa wielu ludzi, dostrzegając wady innych. Piątym: to, że negatywny wizerunek Paska umożliwia dostosowanie do niego schematycznego wizerunku szlachcica-warchoła. Szóstym to, że historia i historia literatury jest poznawana często nie wprost przez lekturę źródeł, lecz dzięki podręcznikom. Wszystko to czyni łatwiejszym poddanie się argumentacji Ignacego Chrzanowskiego, Aleksandra Brücknera i Romana Pollaka niż Jana Chryzostoma Paska. 